\title{
Reducing discards in a demersal purse-seine fishery
}

\author{
Jorge M.S. Gonçalves ${ }^{\text {a }}$, Luis Bentes, Pedro Monteiro, Rui Coelho, Margarida Corado and Karim Erzini \\ Centro de Ciências do Mar - CCMAR, Universidade do Algarve, FCMA Campus de Gambelas, 8005-139 Faro, Portugal
}

Received 1 October 2007; Accepted 3 March 2008

\begin{abstract}
Fisheries bycatches and discards constitute a significant problem in many fisheries worldwide. Unlike the pelagic purse-seine, the demersal purse seine usually targets high commercial value demersal species such as sea breams (e.g., Diplodus spp., Pagellus spp., Sparus aurata) and the European sea bass (Dicentrarchus labrax), while discards consist mainly of pelagic species and juveniles of the above mentioned species. In order to evaluate the efficiency of a selectivity device in reducing bycatch and consequently of discards in a demersal purse seine fishery, experimental deployments were carried out. The bycatch reducing device (BRD) consisted in the use of a panel of diamond-shaped mesh netting of $70 \mathrm{~mm}$ stretched mesh in the posterior part of the purse seine. Data from 61 experimental fishing trials allowed the evaluation of discards, with Scomber japonicus, Boops boops, Sardina pilchardus, Diplodus bellottii and Belone belone being the main discarded species. The mean discard ratio per set was $0.49( \pm 0.30$ standard deviation $)$. The causes for discarding were also identified, with low commercial value being the most important reason. The results of the trials with BRD, were promising, with an average of $49 \%( \pm 24 \%)$ of the fish escaping per set, especially from those species that are most discarded. Overall, the use of this method for reducing discards can be considered positive for the following reasons: there is no need for structural modification of the fishing gear, the BRD is easy to deploy, and it is efficient in terms of species, sizes and quantities of fish that manage to escape. It therefore has significant benefits for the demersal purse seine fishery and possibly for other "métiers" as well.
\end{abstract}

Key words: Bycatch reducing device / Discard / Fishing impact / Gear selectivity / Fisheries management

Résumé - Réduction des rejets dans la pêche démersale à la senne tournante et coulissante. Les prises accessoires et les rejets de pêche sont considérés comme un problème d'importance significative au niveau mondial. Contrairement aux pêches pélagiques effectuées à la senne tournante et coulissante, les pêches démersales réalisées au moyen d'une senne visent essentiellement des espèces à haute valeur commerciale, cas des Sparidae (Diplodus spp., Pagellus spp., Sparus aurata) et du bar (Dicentrarchus labrax). Les rejets comprennent surtout les espèces pélagiques et des juvéniles de ces espèces démersales. Afin d'évaluer l'efficacité d'un engin de sélectivité sur la réduction des prises accessoires, et par conséquent sur les rejets de la pêche à la senne tournante et coulissante, plusieurs expérimentations ont été réalisées. L'engin de réduction de la prise accessoire (BRD) est formé d'un panneau de filet en losange d'un maillage étiré de $70 \mathrm{~mm}$, placé dans la partie postérieure du filet de la senne tournante et coulissante. Les données de 61 pêches expérimentales ont permis l'évaluation des rejets, ainsi Scomber japonicus, Boops boops, Sardina pilchardus, Diplodus bellottii et Belone belone sont les principales espèces rejetées. La proportion de rejets est de 0,49 ( $\pm 0,30$ écart-type) par calée. La faible valeur commerciale est la principale raison du rejet d'une espèce. Les résultats obtenus avec le BRD sont encourageants, avec $49 \%$ ( $\pm 24 \%$ ) en moyenne des poissons qui échappent par calée, notamment des individus des espèces les plus rejetées. Cette méthode ne nécessite pas de modification structurelle de l'engin de pêche et le BRD est facile à déployer; le BRD est efficace au niveau de la taille et des quantités de poissons qui s'échappent. Son utilisation apporte donc des bénéfices significatifs pour la pêche démersale à la senne tournante et coulissante et potentiellement adaptable à d'autres techniques de pêche.

\section{Introduction}

The discarding of non-target species of fish, undersized target species and damaged fish is a common practice worldwide, especially in European fisheries (Saila 1983;

\footnotetext{
a Corresponding author: jgoncal@ualg.pt
}

Alverson et al. 1994; Crean and Symes 1994; Chopin et al. 1995; Clucas 1997; Hall et al. 2000; Borges et al. 2001; Kelleher 2005). Awareness of the extent of the problem and the need for mitigation was initially provoked by the bycatch of charismatic species such as dolphins in tuna (Thunnus albacares) purse seine fisheries in the Northeast Pacific 


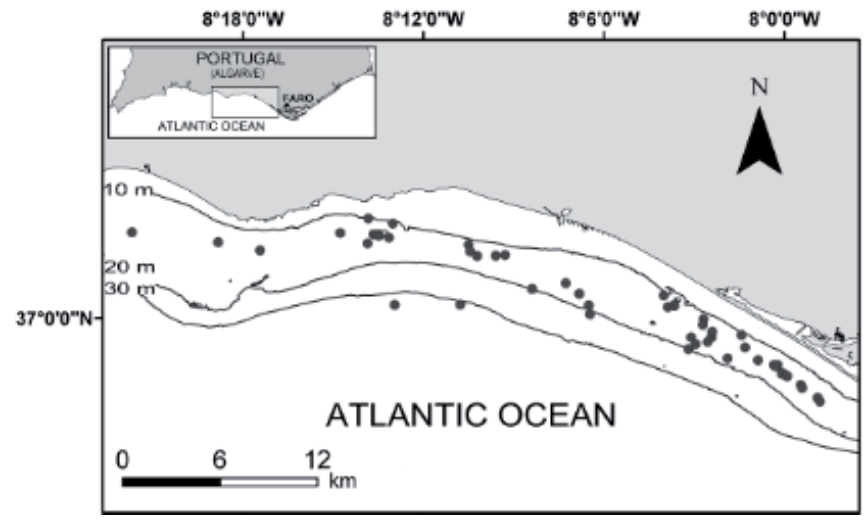

Fig. 1. Location of the experimental fishing operations (Algarve, South of Portugal, North-eastern Atlantic Ocean).

(Hall 1996), but then spread rapidly to other species, especially juvenile fish caught in shrimp trawls (Kennelly and Broadhurst 2002), leading to research on ways of reducing bycatch and mortality rates of fish escaping from fishing gear.

Such studies have been largely based on the understanding of behaviour in relation to fishing gear, gear size selectivity, gear modifications, including selective grids, square mesh panels, cod end separators, turtle exclusion devices (TEDs) and cetacean acoustic avoidance devices (AADs) (e.g., Hall 1994; Broadhurst 2000; Hannah and Jones 2000; Tingley et al. 2000; Revill and Holst 2004; Kelleher 2005). In many cases these mitigation approaches have proved effective in reducing mortality and, in some fisheries, the use of bycatch reduction devices (BRDs) such as grids has become compulsory (Beek et al. 1990; Tingley et al. 2000; Davis and Ryer 2003).

The only study on coastal purse seine bycatch mitigation was on the reduction of bycatch of small fish in saithe (Pollachius virens) and Atlantic mackerel (Scomber scombrus) fisheries in northern European waters. This consisted of the use of rigid metal sorting grids of 30,40 and $44 \mathrm{~mm}$ spacing between bars mounted on the bunt of the purse seine that proved useful in improving the escapement of small saithe (Beltestad and Misund 1995).

Studies off the south coast of Portugal (Algarve) by Borges et al. (2001) have shown that the mean discard rate of purse seiners varies between 20 and $30 \%$ of the total catch. Considering the relative importance of purse seining for landings, it is estimated that in the Algarve alone, purse seine discards represent some 5000 to 10000 t per year (Borges et al. 2001). Although purse seining mainly targets pelagic species, in some areas this gear has been modified for the capture of demersal species in relatively shallow water and has a very specific discard composition (Tingley et al. 2000; Borges et al. 2001). In the south of Portugal 49 out of 106 purse seiners (46.2\%) are the so called "rapas", i.e., vessels that practice demersal seining (Docapesca S.A., unpub. data). Little is known of the impact of these discards on the marine ecosystem, or even on species or populations.

The main objective of this study was to evaluate the efficiency of a selectivity device in reducing bycatch and consequently of discards in a demersal purse seine fishery, using the Algarve fishery as an example. While the demersal purse seine may have the same target species as the pelagic purse seine, it usually targets high commercial value demersal species such as sea breams (e.g., Diplodus spp., Pagellus spp., Sparus aurata) and the European sea bass (Dicentrarchus labrax). In this case it is largely the low value pelagic species such as chub mackerel and sparid juveniles that are discarded.

The study consisted of the experimental deployment of a panel of diamond-shaped mesh netting of $70 \mathrm{~mm}$, in the posterior wing of the purse seine, known as the cuba de vante as a selectivity device. At the end of each purse seining operation, the catch is concentrated near the fishing vessel and the pelagic species, along with small-sized individuals of other species, are forced against the selectivity device and are thus able to pass through and escape.

\section{Material and methods}

\subsection{Discard evaluation}

In general demersal purse-seiners only fish like pelagic purse seiners when the demersal resources are scarce or when pelagic species such as the sardine are economically advantageous. Our study focused only on the demersal purse seine component of this fleet and therefore only purse-seine sets targeting demersal species were considered. Experimental fishing took place in the Algarve, southern Portugal, from April 2003 to July 2004, at depths ranging from 10 to $33 \mathrm{~m}$ (Fig. 1).

In order to evaluate the discard variability and the efficiency of a selectivity device, an experimental study was carried out with a chartered small-scale commercial purseseiner (Length Over All (LOA): 12 m; Gross Register Tonnage (GRT): 14 tonnes; engine horsepower: $134 \mathrm{hp}$; crew: 8). The specifications of the fishing gear were in accordance with normal demersal purse-seine fishing practices, i.e., the floatline and leadline lengths were 200 and $220 \mathrm{~m}$, respectively, with a height of $35 \mathrm{~m}$ and netting of $18 \mathrm{~mm}$ mesh size (Fig. 2).

The evaluation of discards involved the observation of 61 sets where catches were classified following the recommendations of Clucas (1997) and Kelleher (2005). Identification and quantification of the catches and the discards was largely carried out in the laboratory as the fishing vessel was small, with limited workspace. Thus, in the case of relatively large quantities of discards, random sub-samples of discards of 20$40 \mathrm{~kg}$ were taken after the catch had been sorted, and the total amount on board estimated using the number of standard fish boxes.

In the laboratory, samples were sorted to the species level and all the fish and cephalopods measured (to the nearest $\mathrm{mm}$ ) and weighed (to the nearest $\mathrm{g}$ ). The total weights per species in each sample were then used to estimate the total amounts discarded per set. For each trip, the number, location, depth, time and duration of each set was recorded.

All species caught were classified by their frequency of discarding (number of sets in which a species is discarded / total number of sets) $\times 100$ ) according to 3 levels: Freq. $<33 \%$ occasionally discarded; $33 \%<$ Freq. $<67 \%$ frequently discarded, and Freq. $>67 \%$ regularly or always discarded. The reasons for discarding were also identified and recorded for each species and occasion. 

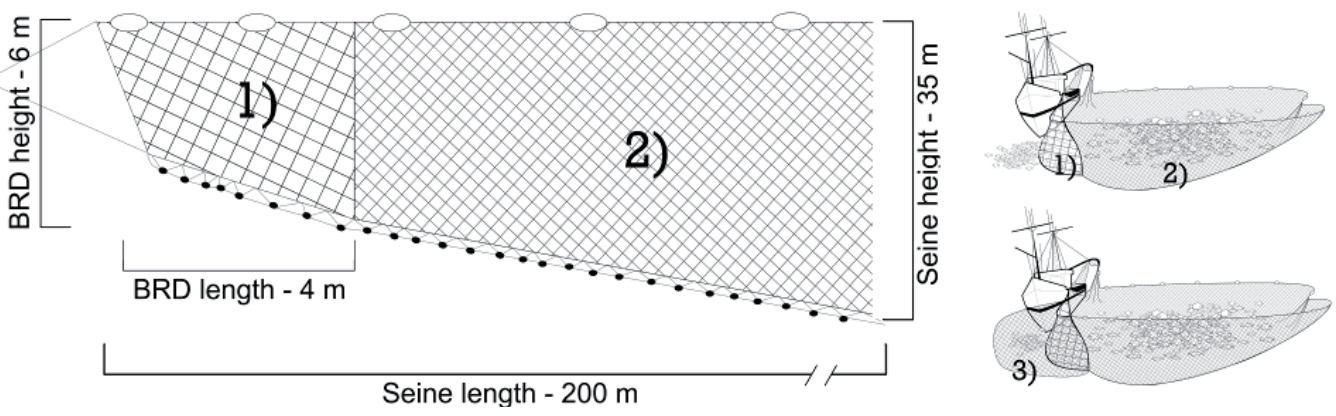

Fig. 2. Left: schematic diagram of the demersal purse seine net with the posterior wing tested as a BRD, (1). BRD stretched mesh and twine sizes: 70 and $2 \mathrm{~mm}$, (2) Seine mesh and twine sizes: 18 and $0.6 \mathrm{~mm}$. Right: Schematic presentation of the BRD in operation. Up: a $70 \mathrm{~mm}$ diamond mesh panel is dropped into the water allowing the escapement of smaller and other unwanted fish; Down: a fine mesh (18 mm) cover (3) was used to retain the escaped fish and allowed the evaluation of the size selectivity of the BRD and the effectiveness in reducing by-catch (illustrations by Frederico Oliveira).

\subsection{Design, construction and experimentation of the selectivity device}

Searching for a simple solution that reduces bycatch and does not involve complex or expensive technology, it was decided together with the fishermen, to evaluate the use of a panel of diamond-shaped mesh netting of $70 \mathrm{~mm}$ (blue polyethylene; of $2 \mathrm{~mm}$ diameter), in the posterior part of the purse seine, known as the cuba de vante (Fig. 2). This panel is essential to the operation of the gear but it is always pulled outside the water when the circle is complete and the net closed (pursed) at the bottom. If this panel could again be lowered into the water before the fish are lifted aboard, it would function as a selectivity device and simultaneously as a bycatch reducing device (BRD). As the net is pursed, the catch is concentrated near the fishing vessel and the pelagic species, along with small-sized individuals of other species are forced against this selectivity device and are thus able to pass through and escape (Fig. 2).

Following other studies on trawl selectivity and BRD (see Broadhurst 2000) an $18 \mathrm{~mm}$ mesh cover $(0.6 \mathrm{~mm}$ diameter monofilament nylon) similar to the principal seine net was used to evaluate the selectivity of the bycatch reducing device.

Experimental fishing was conducted following normal fishing practices (e.g., areas, departure hours, search times and fishing grounds). In the cases where very large quantities were discarded without the entire catch being brought on board i.e. the deployment of the double bag would not be possible ( 5 out of 13 sets), the skipper of the fishing vessel was asked to provide an estimate of the total amount discarded.

Identification, quantification and biometric measurements of the escapees were done in the laboratory and random subsamples were only taken when large amounts of fish remained inside the double bag, following the same procedure as in the discards evaluation section.

\subsection{Data analysis}

The proportion of discard weight of each species to the total discards weight and the proportion of escaped fish to the total weight of escaped fish were calculated. The discards/total catch ratio $(\mathrm{D} / \mathrm{T})$, and the $\mathrm{BRD} /$ total catch ratio $(\mathrm{B} / \mathrm{T})$, in terms of weight, were calculated separately for each species and set and for the sum of all trials. The percentage of escapees (BRD specific efficiency), was determined by species:

$$
[\mathrm{BRD} i /(\mathrm{BRD} i+\mathrm{Discard} i+\text { Landing } i)] \times 100
$$

where $\mathrm{BRD} i$ is the amount of fish of species $i$ caught in the fine mesh cover;

Discard $i$ is the amount of bycatch of species $i$ inside the purse seine that would be discarded; Landing $i$ is the amount of individuals of commercial species $i$ that were retained in the net.

Depending on the results of normality and homoscedasticity tests, ANOVA or Kruskal Wallis ANOVA on ranks were used to compare mean lengths of the species that had individuals simultaneously in at least in 2 of the 3 categories (landings, discards and escaping throughout the BRD): Belone belone, Boops boops, Diplodus bellottii, Diplodus vulgaris, Sardina pilchardus, Scomber japonicus, Spondyliosoma cantharus and Trachurus trachurus. Student-Newman-Keuls or Dunn multiple comparisons were used to test for significant differences among means (Snedecor and Cochran 1989). ANOVAs were carried out using Statistica (StatSoft 1996).

The proportion retained in cover by size class was used to estimate the parameters of the logistic selectivity curve by non-linear least squares regression (SAS Institute Inc. 1988):

$$
P_{j}=\frac{1}{1+e^{-b \times\left(l_{j}-l_{50}\right)}} .
$$

Where $P_{j}$ is the proportion retained by size class $j b$ is the slope of the logistic curve, $l_{j}$ is the mid-point of size class jand $l_{50}$ is the size at $50 \%$ selectivity.

\section{Results}

\subsection{Discarding practices}

Observers went on 26 fishing trips during which 61 valid demersal purse seine sets were carried out. It should be noted 
Table 1. Mean weight and standard deviation (SD) of each fish species caught per set; total weight of each species caught for 61 sets (kg and $\%)$ and the discards/total catch ratio $(\mathrm{D} / \mathrm{T})$.

\begin{tabular}{|c|c|c|c|c|c|c|}
\hline \multicolumn{2}{|c|}{ Species } & \multicolumn{2}{|c|}{$\begin{array}{c}\text { Catch/set } \\
(\mathrm{kg})\end{array}$} & \multicolumn{2}{|c|}{$\begin{array}{l}\text { Total } \\
\text { Catch }\end{array}$} & \multirow{2}{*}{$\begin{array}{c}\mathrm{D} / \mathrm{T} \\
\%\end{array}$} \\
\hline & & Mean & SD & $(\mathrm{kg})$ & $(\%)$ & \\
\hline Chub mackerel & Scomber japonicus & 168.0 & 370.2 & 5739 & 35.1 & 82.4 \\
\hline European pilchard & Sardina pilchardus & 91.7 & 169.7 & 2190 & 13.4 & 44.3 \\
\hline Bogue & Boops boops* & 39.6 & 58.1 & 1718 & 10.5 & 96.4 \\
\hline Common two-banded seabream & Diplodus vulgaris* & 52.4 & 68.4 & 1394 & 8.5 & 2.9 \\
\hline Striped seabream & Lithognathus mormyrus* & 37.0 & 30.8 & 1072 & 6.6 & 0.0 \\
\hline Axillary seabream & Pagellus acarne* & 76.2 & 235.8 & 983 & 6.0 & 0.1 \\
\hline Black seabream & Spondyliosoma cantharus* & 26.5 & 48.6 & 709 & 4.3 & 15.4 \\
\hline Atlantic horse mackerel & Trachurus trachurus & 24.6 & 28.0 & 702 & 4.3 & 11.5 \\
\hline Senegal seabream & Diplodus bellottii* & 28.6 & 47.9 & 624 & 3.8 & 50.2 \\
\hline White seabream & Diplodus sargus* & 12.5 & 16.5 & 287 & 1.8 & 0.0 \\
\hline Garpike & Belone belone & 10.0 & 12.1 & 269 & 1.6 & 84.0 \\
\hline Blue jack mackerel & Trachurus picturatus & 29.2 & 25.9 & 102 & 0.6 & 36.5 \\
\hline European seabass & Dicentrarchus labrax & 11.4 & 13.4 & 91 & 0.6 & 0.0 \\
\hline
\end{tabular}

* Sparidae.

that demersal purse seining is a daily activity, taking place near the port of origin, with trips lasting on average $9 \mathrm{~h} 30 \mathrm{~min}$. Three to six sets each with an average duration of $45 \mathrm{~min}$ are made per trip. The average time of displacement and/or search is about 1 hour. Fishing operations begin at sunset and the last set is usually carried out at sunrise.

The total catch was $16360 \mathrm{~kg}$ and consisted of 46 species, of which 40 were fish, 4 molluscs and 2 crustaceans. Although most of the species caught were demersal (30 species; $65.2 \%$ ), $16(34.8 \%)$ pelagic species and one benthic species $(2.2 \%)$, the skate (Raja undulata) were also caught. The 10 most abundant species caught represented $94.2 \%$ of the total catch, of which seven were demersal and all belonging to the Sparidae family (Table 1 ). With the exception of the bogue (B. boops) and the Senegal seabream (D. bellottii), all sparid fish were commercially important and consequently with low discards. The seabass (D. labrax) was the only demersal species not belonging to the Sparidae family included in the top list of commercial species. Pelagic species were heavily discarded, namely the chub-mackerel (S. japonicus) (Table 1).

Overall, discards included 32 species, of which 25 were fish, 5 were cephalopod molluscs and 2 were crustaceans, weighing a total of $8266 \mathrm{~kg}$, or about half (50.5\%; min. 1.3\%, max. $100 \%$ ) of the total catch. However, a single species, $S$. japonicus, accounted for $58.1 \%$ of the discards in biomass (Table 2). The second most important discarded species was $B$. boops followed by $S$. pilchardus. Some other species discarded in large numbers were $D$. bellottii, the garpike $B$. belone and $S$. cantharus. These species, of which 4 out of 6 are pelagic, accounted for $96.8 \%$ of the total discards (Table 2). The twaite shad (Alosa fallax), an anadromous migratory fish was the only threatened species caught.

In general, the total discard ratio $(\mathrm{D} / \mathrm{T})$ was 0.51 , with averages of $0.51 \pm 0.22(\mathrm{sd})$ per fishing day and $0.49 \pm 0.30$ per set. Mean discard values per set were particular high in the case of $S$. japonicus, although as was also the case for the catch
Table 2. Mean weight and standard deviation (SD) of each species discarded per set; total weight of each species discarded for 61 sets ( $\mathrm{kg}$ and \%) and frequency of discarding (classification, \%).

\begin{tabular}{|c|c|c|c|c|c|}
\hline \multirow{2}{*}{ Species } & \multicolumn{2}{|c|}{$\begin{array}{c}\text { Discards/set } \\
(\mathrm{kg})\end{array}$} & \multicolumn{2}{|c|}{$\begin{array}{c}\text { Total } \\
\text { Discards }\end{array}$} & \multirow{2}{*}{$\begin{array}{c}\text { Discard } \\
\text { Freq } \\
(\%)\end{array}$} \\
\hline & Mean & SD & $(\mathrm{kg})$ & $(\%)$ & \\
\hline Scomber japonicus & 76.3 & 195.4 & 4731 & 58.1 & R 89\% \\
\hline Boops boops & 24.0 & 34.8 & 1655 & 20.3 & R 97\% \\
\hline Sardina pilchardus & 15.4 & 27.4 & 970 & 10.8 & R 93\% \\
\hline Diplodus bellottii & 6.4 & 8.3 & 313 & 3.7 & R $71 \%$ \\
\hline Belone belone & 3.9 & 5.6 & 226 & 2.5 & R $85 \%$ \\
\hline $\begin{array}{l}\text { Spondyliosoma } \\
\text { cantharus }\end{array}$ & 2.5 & 3.1 & 109 & 1.3 & F 66\% \\
\hline Trachurus trachurus & 2.4 & 4.1 & 81 & 0.9 & F $54 \%$ \\
\hline Diplodus vulgaris & 2.3 & 4.4 & 41 & 0.6 & $\mathrm{O} 6 \%$ \\
\hline
\end{tabular}

Regularly (R), Frequently (F), Occasionally (O) discarded.

values, there was a great amount of variability associated with discarding (Table 2).

The five species with highest discard frequencies were $B$. boops followed by $S$. pilchardus, S. japonicus, B. belone and D. bellottii ("regularly discarded" category) (Table 2). Other frequently discarded species included $S$. cantharus, with values at the upper limit of this classification category, and T. trachurus ("frequently discarded" category).

The most frequent cause of discarding was low commercial value (56.6\% of the cases), followed by under sized (40.0\%), while commercial species were sometimes discarded when insufficient quantities for auction were caught (3.3\%) (Table 3). It was observed that in all sets most, if not all, animals were discarded dead or in such a condition that their survival was unlikely, and most were usually scavenged at the surface by marine birds, namely seagulls (Larus spp.). 
Table 3. Relative importance of the 5 reasons for discarding in each species with corresponding taxon and habitat classification (Pe: pelagic; De: demersal) for the totality of the set (61 sets). LV: low value; SQ: small quantity; SSize: small size; MLS: Minimum Legal Size (CE No. 850/98).

\begin{tabular}{|c|c|c|c|c|c|c|c|}
\hline \multirow[b]{2}{*}{ Species } & \multirow[b]{2}{*}{ Habitat } & \multicolumn{5}{|c|}{ Reason for discarding } & \multirow[b]{2}{*}{ MLS (cm) } \\
\hline & & $\mathbf{L V}$ & $\mathbf{L V}+\mathbf{S Q}$ & LV + SSize & SQ & Illegal size & \\
\hline \multicolumn{8}{|l|}{ Fish } \\
\hline Alosa fallax & $\mathrm{Pe}$ & & & & $100 \%$ & & 30 \\
\hline Atherina sp. & $\mathrm{Pe}$ & $100 \%$ & & & & & \\
\hline Balistes carolinensis & $\mathrm{De}$ & & $100 \%$ & & & & \\
\hline Belone belone & $\mathrm{Pe}$ & $89 \%$ & $12 \%$ & & & & \\
\hline Boops boops & $\mathrm{Pe}$ & $14 \%$ & $8 \%$ & & & $78 \%$ & 15 \\
\hline Caranx rhonchus & $\mathrm{Pe}$ & & $100 \%$ & & & & \\
\hline Cheilopogon pinnatibarbatus & $\mathrm{Pe}$ & $100 \%$ & & & & & \\
\hline Chelon labrosus & $\mathrm{Pe}$ & $100 \%$ & & & & & 20 \\
\hline Diplodus annularis & $\mathrm{De}$ & & & & & $100 \%$ & 15 \\
\hline Diplodus bellottii $^{(1)}$ & De & & & $48 \%$ & $2 \%$ & $50 \%$ & 15 \\
\hline Diplodus vulgaris ${ }^{(1)}$ & De & & & $38 \%$ & $28 \%$ & $34 \%$ & 15 \\
\hline Engraulis encrasicholus & $\mathrm{Pe}$ & & $100 \%$ & & & & 12 \\
\hline Liza aurata & $\mathrm{Pe}$ & $100 \%$ & & & & & 20 \\
\hline Oblada melanura & De & $100 \%$ & & & & & \\
\hline Pagellus acarne & De & & & & & $100 \%$ & 18 \\
\hline Pagellus bogaraveo & De & & & & & $100 \%$ & 25 \\
\hline Pagellus erythrinus & De & & & & & $100 \%$ & 15 \\
\hline Sardina pilchardus & $\mathrm{Pe}$ & & $99 \%$ & & & $1 \%$ & 11 \\
\hline Sardinella aurita & $\mathrm{Pe}$ & $100 \%$ & & & & & \\
\hline Sarpa salpa & $\mathrm{De}$ & $100 \%$ & & & & & 18 \\
\hline Scomber japonicus & $\mathrm{Pe}$ & & $61 \%$ & & & $39 \%$ & 20 \\
\hline Scomber scombrus & $\mathrm{Pe}$ & & $100 \%$ & & & & 20 \\
\hline Spondyliosoma cantharus & $\mathrm{De}$ & & & & & $100 \%$ & 23 \\
\hline Trachurus picturatus ${ }^{(2)}$ & $\mathrm{Pe}$ & & $75 \%$ & & & $25 \%$ & 15 \\
\hline Trachurus trachurus ${ }^{(1)(2)}$ & $\mathrm{Pe}$ & & & & $16 \%$ & $84 \%$ & 15 \\
\hline \multicolumn{8}{|l|}{ Crustacean } \\
\hline Melicertus kerathurus & $\mathrm{De}$ & & & & $100 \%$ & & 3 \\
\hline Polybius henslowi & $\mathrm{Pe}$ & $100 \%$ & & & & & \\
\hline \multicolumn{8}{|l|}{ Cephalopod } \\
\hline Loligo forbesi $^{(2)}$ & $\mathrm{Pe}$ & & & & & $100 \%$ & 10 \\
\hline Loligo sp. $^{(1)(2)}$ & $\mathrm{Pe}$ & & & & $27 \%$ & $73 \%$ & 10 \\
\hline Loligo vulgaris $^{(2)}$ & $\mathrm{Pe}$ & & & & & $100 \%$ & 10 \\
\hline Octopus vulgaris & $\mathrm{De}$ & & & & $100 \%$ & & $(750 \mathrm{~g})$ \\
\hline Sepia sp. $^{(2)}$ & $\mathrm{De}$ & & & & & $100 \%$ & 10 \\
\hline
\end{tabular}

(1) Species with commercial value that are potentially discarded by sorting error; (2) Species that have sizes below the MLS but were potentially discarded by sorting error.

\subsection{BRD tests}

In the trials using the BRD, large numbers of pelagic and other small fish were observed escaping at high speeds through the panel. No fish became gilled and the species and size selection process continued until fish became exhausted and started to die. At this point the water near the boat was full of scales, mainly from sardines, and the dying fish sank into the bottom of the bunt.

Of the 16 species that managed to escape through the BRD in the eight experimental trials, the five most important species, which represented $97.3 \%$ of total weight escaped, were those that were most discarded (Table 4). S. japonicus dominated the escapees, accounting for $67.9 \%$ of the total biomass that passed through the BRD. The relative importance of the chub mackerel in escaping is equivalent to its preponderance in the discards, with the proportion escaping even higher than the proportion discarded. B. boops was the second species both in the discards and in the escaping biomass, with values around 19-20\%. In the case of S. pilchardus, the proportion of discarded biomass is higher than the one that escaped, with the same situation occurring for $D$. bellottii and $B$. belone.

The proportion of individuals that were able to pass through the BRD to the total of individuals (in weight) was generally high. In fact, in the eight sets the mean escaping biomass (B/T) was $48.5 \pm 24.4 \%$ per set ( $\min 15 \%$; $\max 78 \%$ ) while the total for all eight sets was $61.8 \%$, which shows the importance of this device in the reduction of undesirable 
Table 4. Mean values and standard deviation of the weight of the species that escaped through the BRD per set; total escaped weight ( $\mathrm{kg}$ and \%) BRD/Total catch ratio $(\mathrm{B} / \mathrm{T})$, based on 13 sets.

\begin{tabular}{lccccc}
\hline & \multicolumn{2}{c}{$\begin{array}{c}\text { BRD/set } \\
\text { Skg) }\end{array}$} & \multicolumn{2}{c}{$\begin{array}{c}\text { Total } \\
\text { BRD }\end{array}$} & \multirow{2}{*}{$\begin{array}{c}\text { B/T } \\
\text { S\%ecies }\end{array}$} \\
\cline { 2 - 5 } & Mean & sd & $\mathbf{( k g )}$ & $\mathbf{( \% )}$ & \\
\hline Scomber japonicus & 230.9 & 166.3 & 1663.3 & 67.9 & 38.8 \\
Boops boops & 39.6 & 39.1 & 468.8 & 19.1 & 13.7 \\
Sardina pilchardus & 24.4 & 17.1 & 153.6 & 6.3 & 4.1 \\
Diplodus bellottii & 15 & 10.9 & 65.2 & 2.7 & 1.2 \\
Belone belone & 7.4 & 4.5 & 31.8 & 1.3 & 1.6 \\
Diplodus vulgaris & 9.1 & 5.9 & 23.5 & 1 & 1.1 \\
Trachurus trachurus & 5.8 & 3.7 & 21.9 & 0.9 & 0.4 \\
\hline
\end{tabular}

catches. In terms of individual species escapee percentages in relation to total catch in weight $(\mathrm{B} / \mathrm{T}), S$. japonicus was the species that had the highest contribution, followed by B. boops and to a lesser extent $S$. pilchardus (Table 4).

Considering the BRD specific efficiency, only the above three species had near total success in escaping through the BRD (>85\%), with $B$. belone and the two sparid species (D. bellottii and D. vulgaris) having the worst performances (Table 5).

In five trials with the BRD deployed without the double bag, landing (e.g., D. vulgaris, $S$. cantharus and $L$. mormyrus), discards and BRD (e.g., S. japonicus, B. boops and $S$. pilchardus) estimated compositions did not vary substantially, nor did the importance of the escapees weight for the total catch. The same was not true for the discard ratios $(\mathrm{D} / \mathrm{T})$ which were anomalously high in these sets $(0.76 \pm 0.10)$, contributing to the increase in the total variability. Escapement success of $S$. japonicus, B. boops and S. pilchardus was confirmed, with BRD specific efficiency values above $89 \%$ (Table 6). Overall, the estimated proportion of $S$. japonicus escapees is higher in these sets when compared with the experimental situation, and the same is true for the total weight.

When comparing the size of the escapees $(B R D)$ to that of the same species that were considered as discards or landings in normal fishing operations, there were significant differences between these three group sizes: escapees $(B R D)$, discarded (Discards) and commercial fish (Landings) (Table 7). Depending on the species or species group, at least two of the three groups differed in sizes based on the multiple comparison tests:

1) For B. belone, D. vulgaris, S. cantharus and T. trachurus median size of Landings was significantly higher than $B R D$ and Discards, but median sizes from the latter two groups were similar $(B R D=$ Discard median size $<$ Landings $)$.

2) For B. boops, D. bellottii and S. pilchardus median sizes of the Landings category were significantly higher than Discards which in turn were higher than $B R D(B R D<$ Discard median size < Landings) (Fig. 3).

In general, for each experimental set, the size of the individuals that escaped through the BRD was equal or inferior to that of the same species that were discarded, which in turn was smaller than the commercial size.

The size selectivity of the BRD was more evident for $D$. bellottii, S. cantharus and B. boops, with increasing proportion

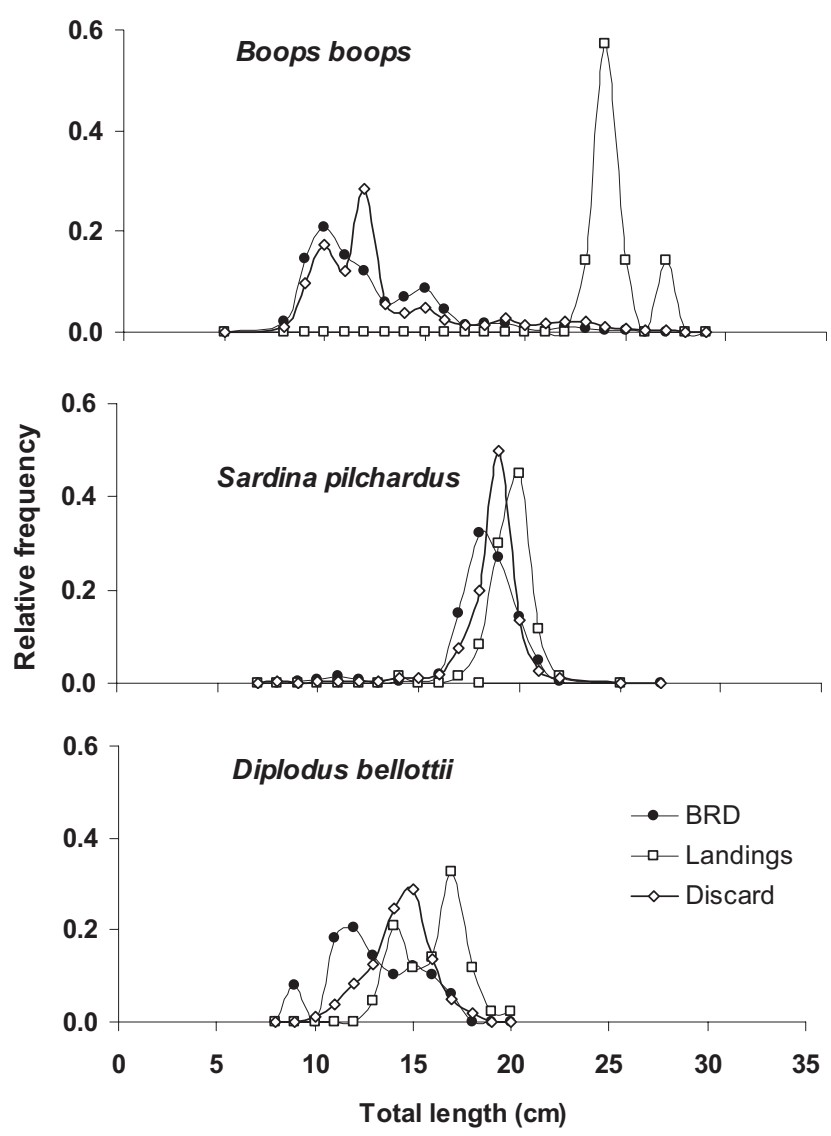

Fig. 3. Length frequency distribution by fate (landings, discards, and escapees through BRD) for bogue (Boops boops), sardine (Sardina pilchardus) and Senegal seabream (Diplodus bellottii).

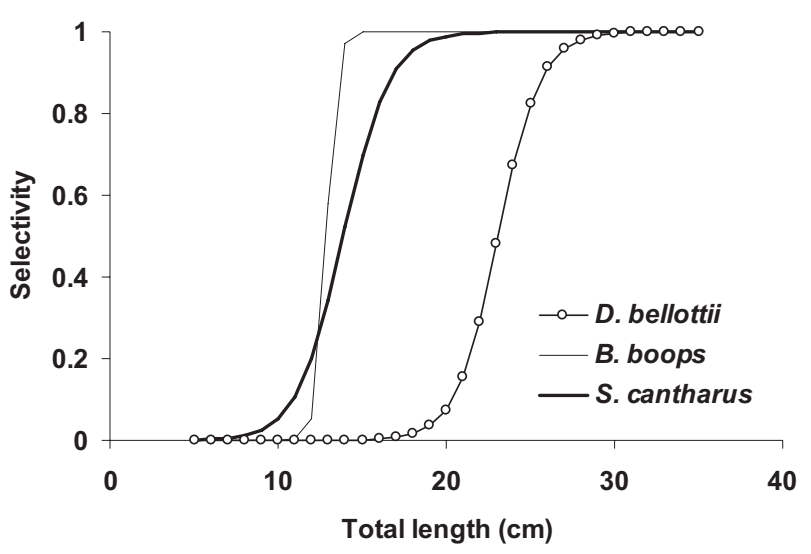

Fig. 4. Length selection curves for Senegal seabream (Diplodus bellottii), black seabream (Spondyliosoma cantharus) and bogue (Boops boops) with a $70 \mathrm{~mm}$ diamond mesh panel (BRD).

retained with increasing size (Fig. 4). The logistic model gave good fits to these three species, with estimated L50 values of $23.1 \mathrm{~cm}$ TL (B. boops), $13.8 \mathrm{~cm}$ TL (S. cantharus) and $12.9 \mathrm{~cm}$ TL (D. bellottii). 
Table 5. BRD, landings (commercial catch), discards (retained onboard) and specific BRD efficiency (\% escapees, total and mean \pm SD) by species, based on 8 sets.

\begin{tabular}{lccccccc}
\hline & & & & & \multicolumn{3}{c}{ BRD Efficiency } \\
\cline { 6 - 8 } \multicolumn{1}{c}{ Species } & BRD & Landings & Discards & Total & Total & Mean/set & SD \\
$(\mathrm{kg})$ & $(\mathrm{kg})$ & $(\mathrm{kg})$ & $(\mathrm{kg})$ & $(\%)$ & $(\%)$ & $(\%)$ \\
\hline Scomber japonicus & 693.3 & 17.0 & 45.9 & 756.3 & 91.7 & 88.3 & 12.7 \\
Boops boops & 244.8 & 0.0 & 42.6 & 287.4 & 85.2 & 91.2 & 8.3 \\
Sardina pilchardus & 73.6 & 3.0 & 4.0 & 80.6 & 91.3 & 91.1 & 13.1 \\
Belone belone & 27.8 & 15.0 & 4.4 & 47.2 & 58.9 & 65.8 & 27.1 \\
Diplodus bellottii & 21.2 & 20.0 & 7.9 & 49.1 & 43.3 & 45.6 & 29.8 \\
Diplodus vulgaris & 19.5 & 242.0 & 0.6 & 262.1 & 7.4 & 5.9 & 5.9 \\
Trachurus trachurus & 6.9 & 2.2 & 0.0 & 9.2 & 75.8 & 87.3 & 26.0 \\
Others & 9.2 & 8.4 & 12.4 & 30.0 & 30.6 & 65.8 & 34.3 \\
\hline
\end{tabular}

Table 6. Estimated BRD, landings (commercial catch), discards (retained onboard) and specific BRD efficiency (\% escapees, total and mean \pm $\mathrm{SD}$ ) by species, based on 5 sets where the BRD was deployed without the fine mesh cover (double bag).

\begin{tabular}{lccccccc}
\hline & & & & & \multicolumn{3}{c}{ BRD Efficiency } \\
\cline { 6 - 8 } \multicolumn{1}{c}{ Species } & BRD & Landings & Discards & Total & Total & Mean/set & SD \\
$(\mathrm{kg})$ & $(\mathrm{kg})$ & $(\mathrm{kg})$ & $(\mathrm{kg})$ & $(\%)$ & $(\%)$ \\
\hline Scomber japonicus & 970 & 0 & 24 & 994 & 98 & 97.8 & 1.9 \\
Boops boops & 224 & 0 & 27.7 & 251.7 & 89 & 79.8 & 23.1 \\
Sardina pilchardus & 80 & 0 & 3.7 & 83.7 & 96 & 33.2 & 57.5 \\
Diplodus bellottii & 44 & 20 & 41.7 & 105.7 & 42 & 41.5 & 27.2 \\
Trachurus trachurus & 15 & 15 & 1.4 & 31.4 & 48 & 32.9 & 57.0 \\
Belone belone & 4 & 0 & 5.4 & 9.4 & 43 & 25.0 & 35.4 \\
Diplodus vulgaris & 4 & 240 & 5.9 & 249.9 & 2 & 1.2 & 1.7 \\
Spondyliosoma cantharus & 4 & 60 & 5.1 & 69.1 & 6 & 2.9 & 4.2 \\
Others & 0 & 159 & 13.1 & 172.4 & 0 & 0.0 & 0.0 \\
\hline
\end{tabular}

Table 7. Mean length and standard deviation ( $\mathrm{cm}$ ) of the escapees (BRD), discards and landings for all sets. Statistical analysis: Kruskal-Wallis and Dunn tests, except for D. vulgaris ANOVA and Student-Newman-Keuls (SNK), multiple comparison tests with $p-$ value $(*$ significant differences).

\begin{tabular}{|c|c|c|c|c|c|c|c|c|c|c|c|}
\hline \multirow{2}{*}{ Species } & \multicolumn{3}{|c|}{ Landings (TL cm) } & \multicolumn{3}{|c|}{ Discards (TL cm) } & \multicolumn{3}{|c|}{ BRD (TL cm) } & \multirow{2}{*}{ Test } & \multirow{2}{*}{$p$ value } \\
\hline & $\mathbf{N}$ & Mean & SD & $\mathbf{N}$ & Mean & SD & $\mathbf{N}$ & Mean & SD & & \\
\hline Belone belone & 27 & 45.9 & 4.3 & 192 & 42.3 & 7.1 & 49 & 42.5 & 3.8 & KW/Dunn & $<0.01 *$ \\
\hline Boops boops & 44 & 23.0 & 1.4 & 2912 & 13.4 & 3.9 & 1154 & 12.6 & 3.1 & KW/Dunn & $<0.01 *$ \\
\hline Diplodus bellottii & 43 & 16.4 & 1.7 & 591 & 14.8 & 1.6 & 49 & 13.5 & 2.2 & KW/Dunn & $<0.01 *$ \\
\hline Diplodus vulgaris & 100 & 22.4 & 2.7 & 32 & 16.0 & 3.6 & 4 & 18.5 & 4.3 & ANOVA/SNK & $<0.01 *$ \\
\hline Sardina pilchardus & 60 & 20.0 & 1.2 & 943 & 19.0 & 1.6 & 326 & 18.7 & 1.8 & KW/Dunn & $<0.01 *$ \\
\hline Scomber japonicus & 52 & 24.7 & 1.7 & 1310 & 20.7 & 2.1 & 241 & 22.0 & 2.3 & KW/Dunn & $<0.01 *$ \\
\hline Spondyliosoma cantharus & 59 & 22.9 & 3.2 & 178 & 16.0 & 2.4 & 21 & 14.8 & 1.1 & KW/Dunn & $<0.01 *$ \\
\hline Trachurus trachurus & 40 & 17.2 & 1.7 & 126 & 11.9 & 3.0 & 174 & 12.3 & 3.0 & KW/Dunn & $<0.01 *$ \\
\hline
\end{tabular}

\section{Discussion}

\subsection{Discard evaluation}

The discarding of small, fusiform species such as the bogue, sardine and chub mackerel in almost all sets in this study $(85 \%)$ is in agreement with reports on discards of purse seines from other southern European fisheries. These include Spain where sardines, bogue and horse mackerel constitute most of the discards (CEC 1992), as well as of sardine purse seiners from the north of Portugal where chub mackerel, horse mackerel and anchovies account for most of the bycatch (Stratoudakis and Marçalo 2002). Similarities in terms of discarded species of pelagic and demersal purse seines in
Algarve waters were reported by Borges et al. (2001) and Erzini et al. (2002), with chub mackerel and bogue among the most important discard species in both métiers. The main reasons for the similarity in discard composition of both types of purse seines and also of fish trawlers and trammel netters (Erzini et al. 2002; Gonçalves et al. 2007) are the common fishing grounds and depths $(10-100 \mathrm{~m})$ fished by all these gears and the high abundance levels of the small pelagic species in this region.

The total proportion of discards $(50.5 \%)$ and the mean per day $(50.2 \pm 22.4 \%)$ was greater than that reported by Borges et al. (2001) for the same region. In the earlier study, discards of demersal purse seiners varied from 0 to $100 \%$, with a mean of $20 \%$ in biomass. The differences between the two studies 
may be due to the inter-annual variability in recruitment and abundance that is characteristic of small pelagic species such as chub mackerel in an area where upwelling, precipitation and river flow can vary considerably from year to year, with consequences for the population dynamics of short-lived, fast growing species (e.g., Hannah et al. 2000; Santos et al. 2001; Erzini 2005).

As also reported by Borges et al. (2001), the most common reason for discarding was low commercial value, especially of species such as the bogue, the chub mackerel, the garpike and silversides (Atherina spp.). Even though demersal purse seiners are equipped with sophisticated electronic equipment for detecting schools of fish near the bottom, in most cases the species composition and sizes can not be precisely determined beforehand, often leading to large catches of undesired species and/or undersized fish that are subsequently discarded.

The low commercial value category includes species such as sardine and chub mackerel that, in certain seasons (autumn and winter), are often caught in lesser quantities that are insufficient to warrant sale at auction. Other species such as the two-banded sea bream and the Senegal sea bream when small sized but above the minimum legal size are often discarded as it is considered not worthwhile taking them to auction.

Individuals of a number of species such as Pagellus spp., Diplodus spp. and S. cantharus, as well as horse mackerel (Trachurus spp.) and squid (Loligo spp.) were discarded because they were below the minimum landing size. However, the latter are often kept by the fishermen for their own consumption or for sale on the black (parallel) market. Low commercial value or undersized catches are also the main causes for discarding in the purse seine fisheries of southern Europe, especially in Spain (CEC 1992).

With the exception of one twaite shad (A.fallax), no other vulnerable or protected species were caught (ICN 2006; IUCN 2007). According to a number of demersal purse seine skippers, the bycatch of sharks, sea turtles and marine mammals in this gear is extremely rare, mainly because the fishing grounds are close to shore, at depths less than 25 to $30 \mathrm{~m}$.

\subsection{BRD evaluation}

The use of selective devices to reduce purse seine bycatch has been tested before by Beltestad and Misund (1995), who attempted to reduce the proportion of small mackerel (S. scombrus) and saithe (P. virens) in Norwegian catches. These authors used large mesh panels (with and without knots) as well as rigid metal grids. The large mesh panels were only tested with mackerel and proved unsuccessful due to fish getting stuck in the meshes which made hauling the net difficult. Although good results were obtained with the rigid metal grids in terms of escapement and subsequent survival (especially for saithe), operational difficulties were encountered with the need for hydraulic winches on the larger boats. The grids also occupied a lot of space, were complicated, required too much time to operate and were dangerous to deploy (Beltestad and Misund 1995).

The BRD tested in the current study is innovative for this type of gear and fishery, being successful in terms of species and size selectivity. The BRD does not require any structural modification of the purse seine net, and is simple to use, allowing the smaller fish to escape after the net has been pursed. It should be noted that in the case of the demersal purse seine, the objective is to minimise the bycatch of undersized target species, mostly juvenile sea breams, and non-target or low commercial values species, especially small pelagic fish. With a fairly large mesh size $(70 \mathrm{~mm})$, blocking of meshes with gilled or wedged fish was not a problem, resulting in good escapement of undersized and non-target species that would otherwise be retained in a purse seine of normal mesh size.

It is important to point out that the BRD is already being used by some purse seiners in the Algarve (southern Portugal) since it reduces sorting time. The decrease in bycatch is also advantageous with respect to increased storage capacity on board, given the limited space on these vessels. For the pelagic purse seiners targeting small pelagic fish, the only method available is "slipping" part or all of the catch. This operation is common, especially in the north of Portugal (Stratoudakis and Marçalo 2002), due to daily quotas, undersized fish and mixed catches of target and bycatch of no commercial value that are not worth sorting.

Of the 16 species that were able to escape through the BRD, the chub mackerel, bogue, sardine, Senegal sea bream and garpike were the most important and were also the species that account for most of the discards in this purse seine fishery. The overall efficiency of the BRD, measured as the proportion of the total individuals caught that escaped through the BRD was relatively high for all sets, with a mean of $48.5 \%$ per set and $61.8 \%$ for the eight sets combined. These results highlight the importance of the use of this device for bycatch reduction.

The species that had the highest escapement rates (BRD specific efficiency) were the chub mackerel, bogue and sardine, along with two sparids, D. vulgaris and $D$. bellottii, and to a lesser extent, horse mackerel (T. trachurus). Small sized horse mackerel, although illegal, are highly sought after. This may be one reason why fishermen are sometimes unwilling to use the BRD as small horse mackerel would easily pass through the $70 \mathrm{~mm}$ mesh.

The high escape rates of small pelagic fish was expected, as were those of small sparids, with the differences between species being attributed to behavioural differences, schooling, resistance, swimming speed, reactions and vision in relation to the gear (Misund 1994; Glass et al. 1995; Gray et al. 2000). In this regard studies of fish behaviour in relation to trawls are highly relevant (e.g., Engas 1994; Valdemarsen and Isaksen 1994).

As reported by Beltestad and Misund (1995), the purse seine is relatively selective for species or groups of species, but not necessarily for sizes. This is because purse seines target schools of fish that are generally more homogenous in terms of species than sizes. However, in the south of Portugal, this gear is not as species-selective as in the North of Europe, because of the much higher species diversity and the fact that demersal purse-seines fish the entire water column, catching demersal and benthic species as well.

The lack of BRD size-selectivity for pelagic species indicates that the $70 \mathrm{~mm}$ mesh is suitable for reducing bycatch of chub mackerel, garpike and sardine. On the other hand, this mesh size retains larger sizes of Senegal sea bream, black sea 
bream and probably also sea bream. For D. bellottii and S. cantharus, the size selectivity allows the capture of commercial sized fish while reducing, but not excluding completely, the bycatch of fish below the MLS (15 and $23 \mathrm{~cm}$, respectively; IGP 2007) and/or the size-at-first-maturity that, in the case of black sea bream, are 20.0 and $22.4 \mathrm{~cm}$ for females and males respectively (Gonçalves and Erzini 2000).

However, for fusiform species such as the bogue, given the relatively large mesh size $(70 \mathrm{~mm})$, size-related behavioural differences probably account for the observed escapement and size selectivity of the BRD. Misund (1994) also found that herring of different sizes behaved differently in relation to pelagic trawls. On the other hand, the retention of small individuals, especially of the bogue, could be due to the lack of contact with the BRD at high catch densities. The BRD remained stretched, with open meshes throughout most of the fishing trials, so closed meshes could not account for decreased escapement.

The BRD was deployed without a cover five times, at the request of the skipper when he judged that the quantity of bycatch exceeded the capacity of our experimental cover. The use of the BRD under these circumstances was clearly beneficial for the fishermen, with large quantities of bycatch escaping. In these sets, the bycatch estimates of the skipper were greater than those predicted from the BRD trials with a cover, but nevertheless reasonable. Finally, the results showed that the efficiency of the BRD was not affected by large catches and support the species-specific and overall estimates of escapement rates recorded in the experimental trials with a cover.

\section{Conclusion}

In summary, the BRD tested in this study proved to be economically beneficial as large fish and species were retained while significant proportions of smaller, non-target species and undersized fish were able to escape. The size-selectivity of the BRD also reduces the time necessary to sort the catch and "cleaner" catches result in an increase in the proportion of onboard storage capacity devoted to commercial species. With decreased handling time, more effort can be put into other activities such as searching and fishing operations. There are also environmental and ecological advantages associated with the use of the BRD, since a decrease in discard rates means reduced impacts at the population, species, community and even ecosystem levels.

The BRD can be used effectively by purse seine fishermen to mitigate bycatch and discards of the demersal purse seine, as well as to increase the landings of larger, high commercial value demersal species. Indeed, this BRD may also be of use in traditional pelagic purse seines, such as those for tuna and may prove a useful management tool in quota-based purse seine fisheries where traditional "slipping" might result in high mortality of small pelagic fish such as sardine. For management of fisheries resources, measures that improve survival of discards or escapees are likely to be more acceptable to fishermen than traditional technical measures such as increasing mesh size (e.g., Mesnil 1996).

In addition to the field trials with the BRD, laboratory studies were also carried out to evaluate the survivorship of fish that managed to escape through this type of BRD. In general, high survival rates were recorded for a variety of species (Gonçalves et al., in prep.), further highlighting the importance of this bycatch mitigation device.

Acknowledgements. We would like to thank all the people, institutions and organizations who contributed directly or indirectly to this study, with special thanks to the skippers Abilio Santos, Jorge Abrantes and José Guerreiro and all the "Maria Eliete" crew for all of their support. Further acknowledgments are extended to our colleagues João Sendão and João Araújo who took part in the laboratory sampling. Funds for this study (POCTI/41331/BSE/2001) were provided by the Portuguese National Foundation for Science and Technology (FCT), which also contributed with a grant to J.M.S. Gonçalves. Finally, we would like to thank the editor and two anonymous reviewers whose comments helped to improve this paper.

\section{References}

Alverson D.L., Freeberg M.H., Murawski S.A., Pope J.G., 1994, A global assessment of fisheries bycatch and discards. Rome, FAO.

Beek V.A., Van Leeuwen P.I., Rijnsdorp A.D., 1990, On the survival of plaice and sole discards in the otter trawl and beam trawl fisheries in the North Sea. Neth. J. Sea Res. 26, 151-160.

Beltestad A.K., Misund O.A., 1995, Size selection in purse seines. In: Solving bycatch: considerations for today and tomorrow. Alaska Sea Grant College Program Report No 96-03, pp. 227-233.

Borges T.C., Erzini K, Bentes L., Costa M.E., Gonçalves J.M.S., Lino P.G., Pais C., Ribeiro J., 2001, By-catch and discarding practices in five Algarve southern Portugal metiers. J. Appl. Ichthyol. 17, 104-114.

Broadhurst M.K., 2000, Modifications to reduce bycatch in prawn trawls: a review and framework for development. Rev. Fish Biol. Fish. 10, 27-60.

CEC, 1992, Report from the Commission to the Council on the discarding of fish in Community fisheries: causes, impact, solutions. Brussels, Commission of the European Communities, pp. 1-50.

Chopin F., Inoue Y., Matsushita Y., Arimoto T., 1995, Sources of accounted and unaccounted fishing mortality. In: Solving bycatch: considerations for today and tomorrow. Alaska Sea Grant College Program Report No $96-03$, pp. 41-47.

Clucas I., 1997, A study of the options for utilization of bycatch and discards from marine capture fisheries. Rome, FAO.

Crean K., Symes D., 1994, The discards problem: towards a European solution. Mar. Pollut. 18, 422-434.

Davis M.W., Ryer C.H., 2003, Understanding fish bycatch discard and escapee mortality. AFSC Quartely Report, Seattle, pp. 1-9.

Engas A., 1994, The effects of trawl performance and fish behaviour on the catching efficiency of demersal sampling trawls. In: Ferno A., Olsen S. (Eds.) Marine Fish Behaviour in Capture and Abundance Estimation. Oxford, Fishing News Books, pp. 45-65.

Erzini K., Costa M.E., Bentes L., Borges T.C., 2002, A comparative study of the species composition of discards from five fisheries from the Algarve southern Portugal. Fish. Manage. Ecol. 9, 3140.

Erzini K., 2005, Trends in NE Atlantic landings (southern Portugal): identifying the relative importance of fisheries and environmental variables. Fish. Oceanogr. 14, 195-209. 
Glass C.W., Wardle C.S., Gosden S.J., Racey D.N., 1995, Studies on the use of visual stimuli to control fish escape from codends. Part I. Laboratory studies on the effect of a black tunnel on mesh penetration. Fish. Res. 23, 157-164.

Gonçalves J.M.S., Erzini K., 2000, The reproductive biology of the black sea bream, Spondyliosoma cantharus (L.) from the SW Coast of Portugal. Sci. Mar. 64, 403-411.

Gonçalves J.M.S., Stergiou K.I., Hernando J.A., Puente E., Moutopoulos D.K., Arregi L., Soriguer M.C., Vila C., Coelho R., Erzini K., 2007, Discards of experimental trammel nets in southern European small-scale fisheries. Fish. Res. 8, 5-14.

Gray C.A., Larsen R.B., Kennelly S.J., 2000, Use of transparent netting to improve size selection and reduce selectivity and reduce bycatch in fish seine nets. Fish. Res. 45, 155-166.

Hall M.A., 1994, Bycatch in purse-seine fisheries. In: Pitcher T.J., Chuenpagdee R. (Eds.) Bycatches in fisheries and their impact on the ecosystem. The Fisheries Centre, Vancouver, University of British Columbia, pp. 53-58.

Hall M.A., 1996, On bycatches. Rev. Fish Biol. Fish. 6, 319-352.

Hall M.A., Alverson D.L., Metuzals K.I., 2000, Bycatch: problems and solutions. Mar. Pollut. Bull. 411-6, 204-219.

Hannah R.W., Jones S.A., 2000, By-catch reduction in an ocean shrimp trawl from a simple modification to the trawl footrope. J. Northw. Atl. Fish. Sci. 27, 227-233.

Hannah C.G., Shore J.A., Loder J.W., 2000, The drift retention dichotomy on Browns Bank: a model study of interannual variability. Can. J. Fish. Aquat. Sci. 57, 2506-2518.

ICN, 2006, Livro vermelho dos vertebrados de Portugal. Lisboa, Instituto de Conservação da Natureza, ICN.

IGP, 2007, Portuguese Fisheries Inspection Department. Minimum legal sizes. http://www.igp.pt. Downloaded on September, 4, 2007.

IUCN, 2007, IUCN Red List of Threatened Species. http://www. iucnredlist.org. Downloaded on September, 4, 2007.
Kelleher K., 2005, Discards in the world's marine fisheries: an update. FAO Fish. Tech. Paper 470, 1-131.

Kennelly S.J., Broadhurst M.K., 2002, By-catch begone: changes in the philosophy of fishing technology. Fish Fish. 3, 340-355.

Mesnil B., 1996, When discards survive: Accounting for survival of discards in fisheries assessments. Aquat. Living Resour. 9, 209215.

Misund O.A., 1994, Swimming behaviour of fish schools in connection with capture by purse-seine and pelagic trawl. In: Ferno A., Olsen S. (Eds.) Marine Fish Behaviour in Capture and Abundance Estimation. Oxford, Fishing News Books, pp. 84106.

Revill A.S., Holst R., 2004, Reducing discards of North Sea brown shrimp (C. crangon) by trawl modification. Fish. Res. 68, 113122.

Saila S.B. 1983, Importance and assessment of discards in commercial fisheries. FAO Fish. Circ. No. 765, 1-62.

Santos A.M.P., Borges M.F., Groom S., 2001, Sardine and horse mackerel recruitment and upwelling off Portugal. ICES J. Mar. Sci. 58, 589-596.

SAS Institute Inc., 1988, SAS/STAT* User's Guide. Release 6.03. NC: SAS Institute Inc.

Snedecor G.W., Cochran W.G., 1989, Statistical Methods. Iowa State University Press/AMES.

StatSoft, Inc. 1996, STATISTICA for Windows. Tulsa, StatSoft, Inc.

Stratoudakis Y., Marçalo A., 2002, Sardine slipping during purseseining off northern Portugal. ICES J. Mar. Sci. 59, 1256-1262.

Tingley D., Erzini K., Goulding I., 2000, Evaluation of the state of knowledge concerning discards practices in European Fisheries. European Parliament, MegaPesca.

Valdemarsen J.W., Isaksen B., 1994, Bycatch reduction in trawls by utilizing behavioural differences. In: Ferno A., Olsen S. (Eds.) Marine Fish Behaviour in Capture and Abundance Estimation. Oxford, Fishing News Books, pp. 69-83. 